\title{
26 頭部外傷による聴賞障害
}

石含武雄 河村正三 久保田靪 O渡边洋(順大)

先に我マは後迷路性難聴の診断、特に後迷路性難聴の病菓部位の診断に対にて、 下記に示才聴覚検查オ法を病理解剖学的知見により比較検討にた。その結果，時间 歪両耳合成検查と方向感検查では下丘（我々は各種临床梌查成績を綜合して㯖覚線 維の交ヌレブは主とはて下丘の高さであろうと考之る)なり下部の脳幹部の障害 て異常が現われ易…nに対して，周波数歪棓音検查及で時间企語音検查では中枢㯖 党释路のいかなる部位に病变があっても異常となる。1かし Tone Decay Testは側顽 莱障害で主脳幹部障害でも現われるが異常例数が少、為にもの診断的洒犆は不明で 直る。今回は:れ等をもとにくて、頭部外傷の患者に同し检查を实施する:とによ り，乡の中から後迷路性難聴を診断するとともに、あわせて:れ算検查オ法の診断 的牺值を㭘討した。

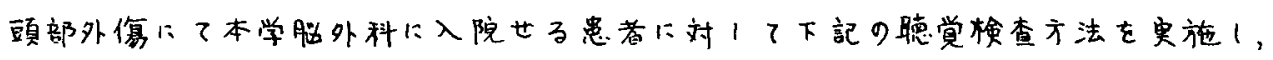
そのうち後迷路性障害を推定し得る19例につ、て㭘討した。

1 、気導及ご骨導紲音域値検查

2. 通常の棓音検查

3.リ7ルートメント現象の检查

4. Tone Decay Test

5、周波数歪棓音検查（2400 LOW PASS 7ィルターを便用し最高明瞭度值を求 め了。語音は57 A，Bの一音節語表を便用)

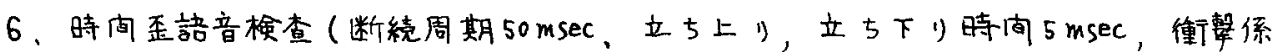
数50\%の需子スイッチを使用に最高明敗度值を求める。使用した弪表は日常会話に 用いるもので理解(やす、有意の二音節単語26よりなる)

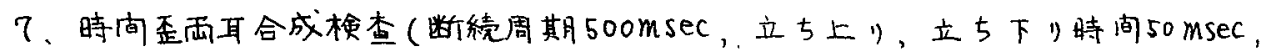

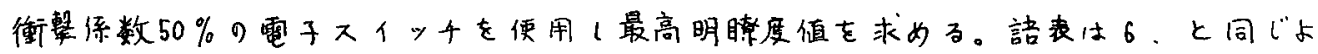
うなものを作成(使用)

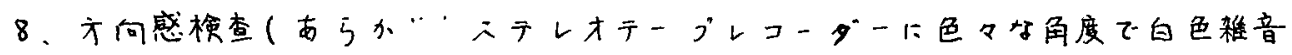

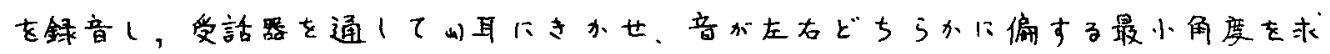
め之れを域值とする)

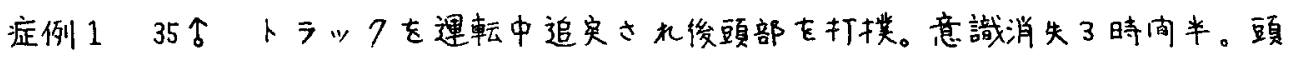

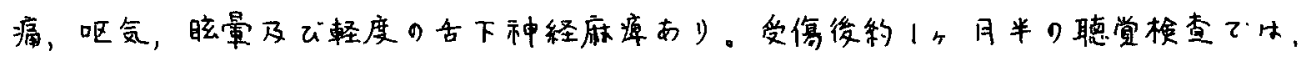
維音域值㯖力国は四の如し、クルートメント㓌性。通常の語音検查異常。Tone Decay Test 左異常。才向感検查正常。両耳合成㭘查明睹度值低下。周波数歪及公時 间歪語音検查何れも雨側共明睹度值低下。

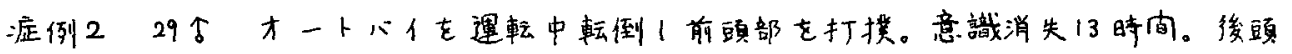

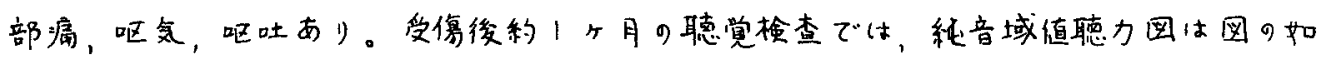

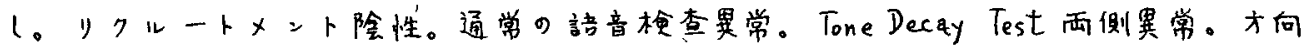
Audiology Vlo. 9, No. 2. 1966 
95

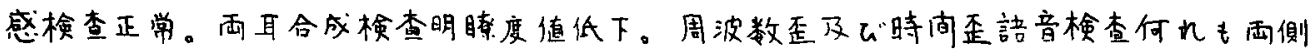
共明瞭度值低下。

全19例において、通常の語音㭘查にては全例中9例（4例は両側性に，5例は片

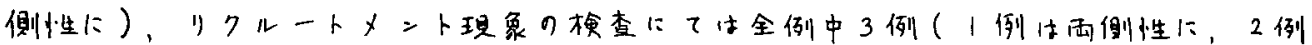
は片側性に)に異常が認められた。そいて：の19例は全ていわ中る中枢性難㯖の為 の5つの梌查す法で何等

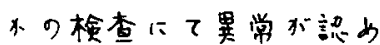
られた。すなわ市 Tone Decay Test $1: 2$ \&全例中 7例（４例付禹側性々， 了例は片側性に)，方向 感㛟查下了小全例中8例， 禹耳合成检查に乙心全例 中5例，周波数歪語音検 查:ては全例中10例- $-(-4$ 例は乘側性1，6例は片 側性:)，睦闪歪語音榆 查に了は全例中12例（6

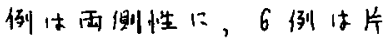
側性下) に異常心゙認め了 社。

各々の椱查间の阅保を

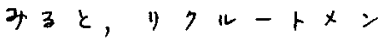

卜晹性の3例では5 万 㭘查のう52つ以上が果 常者示1大。Tone Decay 諰为られたて例では，全 乙の例几周波数歪あ 3 . は時闪走語音検查のどち

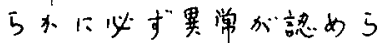
九下。方向感㭘查:罢常 を示す8例については， 周波数䄳及云時间歪語音 検查にて異常を示す例が それ光”れ2例，西方共に 異常を示す例が1例で南 症例 135 个

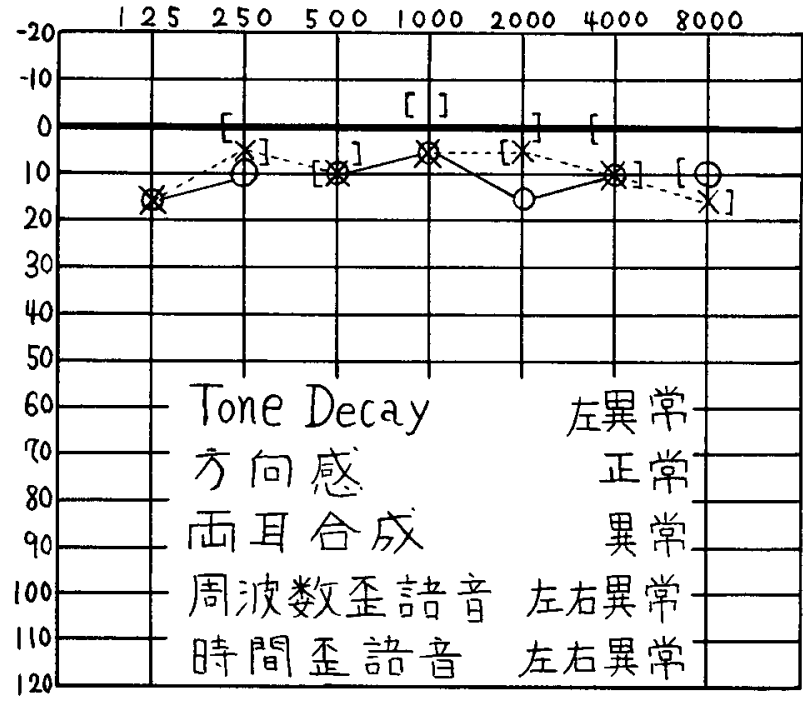

$$
\text { 症例 } 29 \text { 个 }
$$

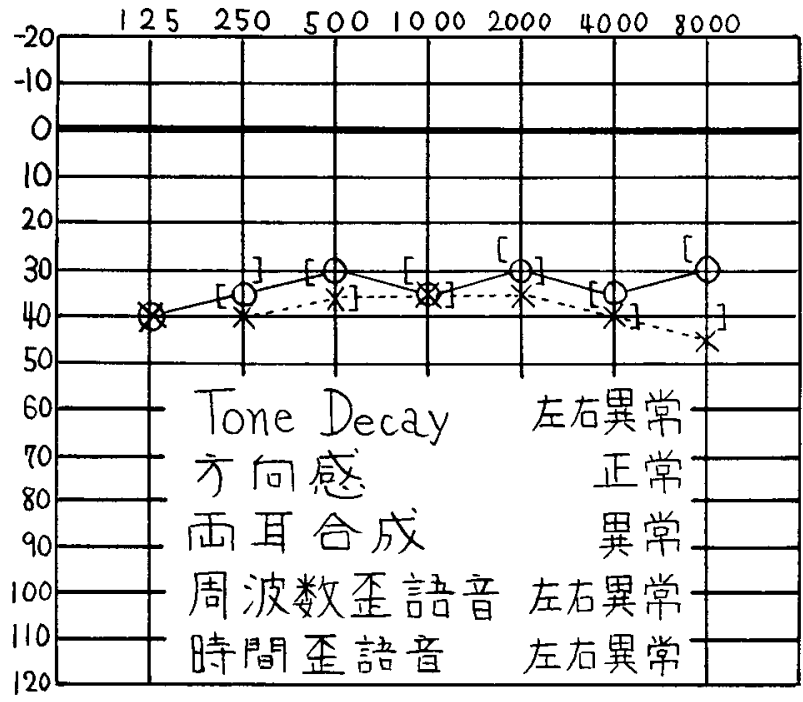

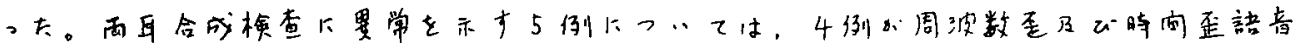

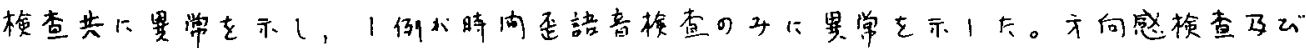
两耳合成梅查共:是常を示す例は例であ。た。 